\title{
The functional and spatial transformation in the Golden Horn
}

\author{
F. Onal \& S. Zeybekoglu \\ Faculty of Architecture, Yildiz Technical University, Turkey
}

\begin{abstract}
Istanbul is the only city in the world that spreads over two continents: it lies at a point where Asia and Europe are separated by a narrow strait. It has been the capital of three great empires, the Roman, Byzantine and Ottoman empires. The Golden Horn is an estuary dividing the city of Istanbul. The name Golden Horn is both a symbol of fertility because of the fertile lands on its shores, the fresh water of the streams and a reference to its shape. Throughout history the Golden Horn has been an important center where the economic, cultural, social and military activities of the historical city took place. It has also played an important role in the development of the city.

Today the functional and spatial transformation of the Golden Horn is explicitly visible. In recent years, thousands of buildings on the shores of the Golden Horn have been demolished, whereas historic shipyard and the industry businesses moved to outside of the city. Museums, cultural and exhibition centers, and university settlements began to locate along the shore, which triggered various restoration projects. These changes and transformations in the Golden Horn affect social, economical and cultural life of the city in general. Seeing that the transformation that has been taking place in and around the Golden Horn does not follow any coherent planning strategy, possible spatial and physical effects of such individual projects on the city and particularly the Historical Peninsula remain uncertain. Consequently, in this paper we want to discuss the future of this historical area as well as its functional and spatial influences on the historic city.

Keywords: transformation, urban space, historic city, the Golden Horn.
\end{abstract}




\section{Introduction}

The change and modernization of cities can be traced from many variables such as the new order generated by the buildings which are intrinsic to modern society, the circulation system of streets, the railways and stations and the residential neighborhoods.

As a result of the competitiveness between cities which has been generated by globalization, the cities strive to be competitive, creative and differentiated. With the new developments in capital accumulation strategies, cities, which were areas for industrial production, are now becoming the new prestige areas in which the service sectors are located. In parallel to neo-liberalism and globalization debates, it has become an important phenomenon to emphasize the intrinsic qualities of the cities in order to attract capital. Within this agenda, city centers are becoming key factors and they are subject to transformation process [1].

Urban transformation projects are effective planning tools for protecting and maintaining a sustainable development of historical areas of the city and redeveloping the depressed areas of the city with their spatial, social and economic qualities [2]. In urban renewal, the economic development is as much important as functional revitalization [3].

The success of urban transformation projects depends on their ability to create a holistic approach to the visions and aims of the city in general. During the last years, the old industrial areas, warehouses or docks of cities, which lost their previous functions, are subject to urban transformation processes. These areas, with their infrastructures and central locations are preferred for transformation projects [4].

In this context, Halic is both a central location and a natural harbor within the city. With many former industrial buildings of historical value, it carries much potential for new transformation projects.

\section{Theoretical approaches to urban regeneration concept}

Urban Regeneration should not be considered as only spatial transformation, it also includes the effects of these transformations on the social, cultural and economic structure of the city. Thus, the regeneration concept includes preservation, rehabilitation and renovation along with spatial transformation [5].

The main feature of urban structure is that it creates a system defined by the relationships between its different parts. In order to understand this system, it is necessary to grasp the whole, which constitutes this system. This whole is defined by Gestalt theory: According to Gestalt psychology; images are perceived as a pattern or a whole rather than merely as a sum of distinct component parts $[6,7]$. In other words, urban structure is a different reality from the sum of its separate parts and it cannot be reduced to their agglomeration.

According to Piaget's general description, the whole of a building or a historical city cannot be reduced to the accumulation of its parts [8]. Thus, what should be protected in a historical city are not mere objects, but the system which they define. 
The order of relationships between its components is what defines the urban structure as a system [9], and the logic of spatial organization becomes manifested within these relationships. The signification level of a historical city can only be understood through the reading of this spatial organization, which defines the image of the city. Any building which have been separated from the system and lost its relationship with the spatial organization will loose their signification levels.

In circumstances where the relationship order is not perceived and protected, it becomes impossible to protect the singular object as well, and this results with "lost spaces" [10]. The buildings which have been rendered unrelated with the urban structure cannot create a signification level. Only if we consider the city as a system of transformations and the real subjects of preservation as the system, then can we have a preservation approach which also maintains the protection of single object.

Elimination of the historical pattern of Halic (the Golden Horn) after the 1980s resulted in the destruction of its system. A small number of buildings which have been "preserved" and left unaccompanied between new parks that replaced the historical fabric have already lost their relationship with the city's urban spaces.

\section{Evolution of Golden Horn (Halic) - historical background}

The superimposition of a history of 3000 years and the dynamics of today's metropolis has resulted with a multilayered and multi cultural structure in Istanbul, which has been, successively, the capital city of Roman, Byzantine and Ottoman Empires. Different layers of late Roman/Pagan, Byzantine/Christian, Ottoman/Muslim and modern Turkey have created the culture of today's Istanbul [11].

The basis of the city's multi-cultural structure was the settlement policies that were effective beginning from the Byzantine period, and then throughout the Ottoman reign. As a result of the policy of settling different ethnic and religious groups in different locations within the city, these groups were able to develop their own sub-cultures within the neighborhoods, and thus see themselves as a part of the empire [12].

Halic was formed at the intersection point of two small rivers, Alibey (Kydaros) and Kagithane (Barbyzes). It is assumed that, the earliest settlements in Istanbul were located on the shores of Halic and up on the hills overlooking the valley. Because of its geographical location and as a safe harbor Halic has always been an attractive area for different cultures. In addition to Istanbul's Greek population, Jews from Spain, Turks and Armenians were settled around Halic and shaped this geography with their building traditions cultures [13].

Halic, which serves as an inner harbor, was not used during the Byzantine period except for the Galata area on its northern shore. Towards the end of the $19^{\text {th }}$ century, in addition to warehouses, which were used to keep military equipment, docks were built on the northern part of Halic. During the Ottoman 
reign, Halic began to be function as a commercial harbor, and more docks were constructed [14].

The topographical qualities of Istanbul, the city which is both separated and joined with Bosphorus, Halic and the Sea of Marmara, gave an exceptional character to developments during the modern period. The modern cities of the $19^{\text {th }}$ century Europe were inclined to expand as circles around a central node. This natural macro form, which surrounds the center and spreads outwards, was not valid for Istanbul mainly due to its topographic conditions [15].

Since the location of Istanbul's historical center was surrounded with Marmara and Halic sea waters, modernization of the city, which gained momentum particularly from the middle of the $19^{\text {th }}$ century, took place on the opposite side of Halic [16]. The old city was left for the groups who were resistant to change, and the ones who were inclined to embrace a modern life started to build a new city on the shores of Halic and Bosphorus in Galata. This distinction between the so-called traditional and modern, the building of the new without almost touching the old is a unique character of Istanbul's modernization.
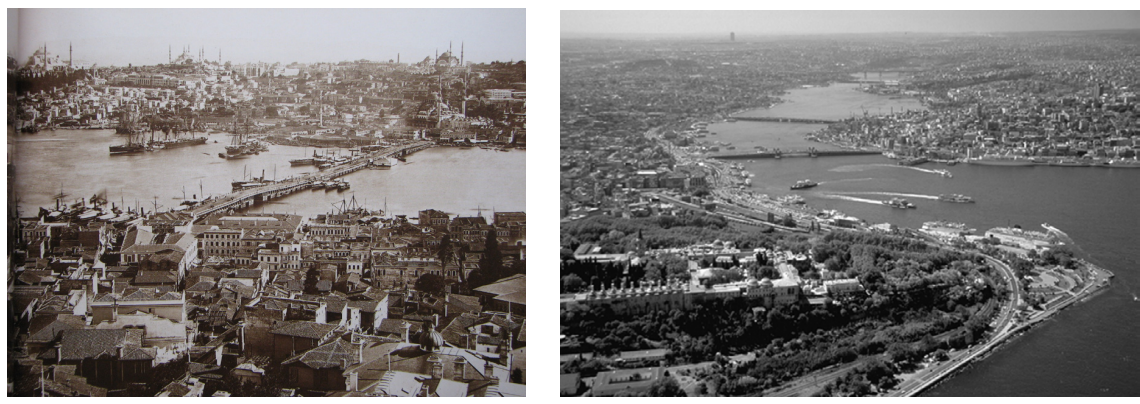

Figure 1: View from Halic in 19th century and in 21 st century.

\subsection{Halic in 1950s}

Halic was a pioneer in many changes which were taking place in Istanbul, and it had a leading role in industrialization efforts of Ottoman Empire during the $19^{\text {th }}$ century. This area, which contained the storehouses as well as various transportation facilities, gained a new appearance with the building of factories and warehouses, while housing settlements lost their significance for the area.

Major urban operations headed by the Prime Minister Adnan Menderes took place during the 1950s. These operations did not take into consideration the new dynamics of the city. These were rapidly growing problems, such as the ones caused by industrialization, immigration and housing shortage. These problems played an important role in the development of Istanbul after the 1950s. Other operations of 1950 s took place within the historical peninsula. The coastal road which surrounded the historical peninsula detached the peninsula from the sea, and destroyed the main character of the city. Similar operations took place in the 1980s and the shores of Halic were covered with coastal roads [17]. 
Modernization which means population growth, urban growth, and industrialization was also the main reason for severe urban problems. During the $19^{\text {th }}$ century, the success of public investments which were made for the city was low compared to other examples in major European cities [18]. The growing during the 1950s has been characterized with the unplanned developments of squatter settlements around the highways [15].

With rapid urbanization and increase in immigration movements directed towards the city from other parts of Turkey, Halic became one of the most problematic areas of Istanbul. The irregular building types caused by rapid urbanization and industrialization trivialized the multi layered and multi cultural structure of Istanbul.

\subsection{Halic after 1980s}

During the 1980s, new highways were constructed around the shores of the old city. The coastal road which was built in the 1950s was connected to the coastal road of Bosporus after the demolitions in Halic and Persembe Pazari area. Again in this period, with the removal of many small enterprises and industrial functions to the peripheries of the city, and decentralization of the area in general, many industrial buildings were demolished without attempts for any documentation. These operations resulted with vacant and empty areas on the shores of Halic [17].

As a result of removal of buildings that have industrial, transportation and military functions from city centers, these areas were abandoned. Due to increase in land values, train stations, docks, and factories began to leave the city centers and these areas, instead of being reused for social functions, became obsolete [19].

The abandoned industrial buildings on the shores of Halic began to attract attention at the beginning of the 1990s. Being accessible to city and having monumental architectural characteristics, these buildings constituted a great potential for the new cultural projects. This process, which is visible today throughout the shores of Halic, starting from Perşembe Pazarı to Eminönü, began with the transformation of Lengerhane building into an Industry Museum in 1991.

This project was followed by the transformation of Feshane-i Amire, a $19^{\text {th }}$ century textile factory, into a congress and cultural center. Later, Haskoy Dockyards were included into industry museum. The building of a cultural center on the previous location of Sutluce Slaughterhouse, which has been demolished in spite of the preservation council's report demonstrate the continuity of this process. The urban rehabilitation project in Fener-Balat area, the transformation of Cibali Tobacco factory into a private university, and the transformation of Silahtaraga Electric Power Plant into the campus and cultural center of another private university can be listed as other considerable examples. 

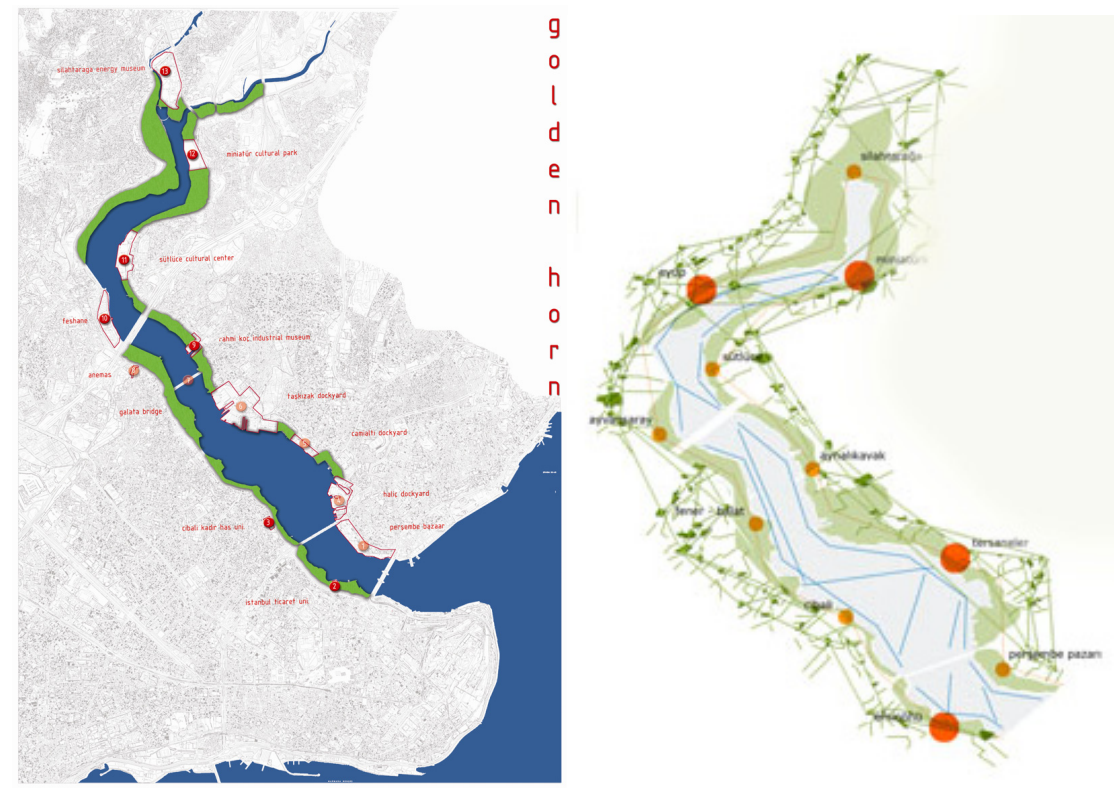

Figure 2: The analysis of industrial buildings in Halic area at the urban scale.

These transformations include two potential problems:

1. These transformations were held without considering the physical and social aspects of the surrounding neighborhoods. They were put into practice followed by top-down decisions.

2. Considering the developments of last 100 , and then 10 years, it is likely that these transformations will cause a gentrification from which speculators will benefit the most.

Hamnett defined gentrification as "simultaneously a physical, economic, social and cultural phenomenon. It involves the physical renovation or rehabilitation of what was frequently a highly deteriorated housing stock and its upgrading to meet the requirements of its new owners. In the process, housing in the areas affected, both renovated and unrenovated, undergoes a significant price appreciation. Such a process of neighborhoods transition commonly involves a degree of tenure transformation from renting to owning [20].

During the history of modern urbanization, any intervention that might appear to transform the city centers and historical areas are also reflected within the dynamics of society. People who are living in the transformed areas had to leave their neighborhoods and a different social group took their places. However, the policy making and implication process may reduce the inequalities between different social groups. 
Table 1: The building dates, functions, owners, new functions and transformation dates of the historical industrial buildings on Halic shores.

\begin{tabular}{|c|c|c|c|c|c|c|}
\hline $\begin{array}{l}\text { Name of the } \\
\text { building }\end{array}$ & Built in & $\begin{array}{l}\text { Original } \\
\text { function }\end{array}$ & Last owner & $\begin{array}{l}\text { New } \\
\text { Function }\end{array}$ & \begin{tabular}{|l|} 
Year of \\
transform \\
ation \\
\end{tabular} & $\begin{array}{l}\text { Building } \\
\text { area }\end{array}$ \\
\hline $\begin{array}{l}\text { Haliç } \\
\text { dockyard }\end{array}$ & 1796 & Dockyard & $\begin{array}{l}\text { Turkish } \\
\text { Maritime } \\
\text { Enterprise }\end{array}$ & - & - & $69.810 \mathrm{~m}^{2}$ \\
\hline $\begin{array}{l}\text { Camialt1 } \\
\text { dockyard }\end{array}$ & 1933 & Dockyard & $\begin{array}{l}\text { Turkish } \\
\text { Maritime } \\
\text { Enterprise }\end{array}$ & - & - & $72.000 \mathrm{~m}^{2}$ \\
\hline $\begin{array}{l}\text { Taşkızak } \\
\text { dockyard }\end{array}$ & 1463 & Dockyard & $\begin{array}{l}\text { Turkish } \\
\text { Republic } \\
\text { Head of } \\
\text { General Staff }\end{array}$ & - & - & $95.000 \mathrm{~m}^{2}$ \\
\hline $\begin{array}{l}\text { Hasköy } \\
\text { Dockyard }\end{array}$ & 1861 & Dockyard & $\begin{array}{l}\text { Maritime } \\
\text { Enterprise } \\
\end{array}$ & \begin{tabular}{|l|} 
Private \\
Museum
\end{tabular} & 2001 & $11.068 \mathrm{~m}^{2}$ \\
\hline Lengerhane & $\begin{array}{l}1703- \\
1730\end{array}$ & $\begin{array}{l}\text { Anchor and } \\
\text { Chain } \\
\text { Factory }\end{array}$ & Municipality & $\begin{array}{l}\text { Private } \\
\text { Museum }\end{array}$ & 1994 & $7.113 \mathrm{~m}^{2}$ \\
\hline $\begin{array}{l}\text { Sütlüce } \\
\text { slaughter } \\
\text { house }\end{array}$ & 1920 & $\begin{array}{l}\text { Slaughter } \\
\text { house }\end{array}$ & Municipality & \begin{tabular}{|l|} 
International \\
congress \\
center
\end{tabular} & $1998-\ldots$. & $\underset{+}{46.000 \mathrm{~m}^{2}}$ \\
\hline & & & & & & $73.000 \mathrm{~m}^{2}$ \\
\hline $\begin{array}{l}\text { Silahtarağa } \\
\text { Electric } \\
\text { Power Plant }\end{array}$ & $\begin{array}{l}1911- \\
1950\end{array}$ & $\begin{array}{l}\text { Electric } \\
\text { Power Plant }\end{array}$ & $\begin{array}{l}\text { Turkish } \\
\text { Electric } \\
\text { Enterprise }\end{array}$ & $\begin{array}{l}\text { Private } \\
\text { University, }\end{array}$ & $2004-\ldots \ldots$ & $\begin{array}{l}107.000 \\
\mathrm{~m}^{2}\end{array}$ \\
\hline Feshane & 1836 & $\begin{array}{l}\text { Fes Making } \\
\text { Factory }\end{array}$ & Municipality & $\begin{array}{l}\text { Congress } \\
\text { and Culture } \\
\text { center }\end{array}$ & 1998 & $\begin{array}{l}\frac{64.000 \mathrm{~m}^{2}}{+} \\
8.000 \mathrm{~m}^{2}\end{array}$ \\
\hline $\begin{array}{l}\text { Cibali } \\
\text { Tobacco } \\
\text { Factory }\end{array}$ & 1884 & $\begin{array}{l}\text { Tobacco } \\
\text { Factory }\end{array}$ & $\begin{array}{l}\text { Turkish } \\
\text { Monopoly }\end{array}$ & $\begin{array}{l}\text { Private } \\
\text { University }\end{array}$ & 1998 & $35,000 \mathrm{~m}^{2}$ \\
\hline $\begin{array}{l}\text { Chamber of } \\
\text { commerce } \\
\text { building }\end{array}$ & 1963 & $\begin{array}{l}\text { Office } \\
\text { building }\end{array}$ & $\begin{array}{l}\text { Chamber of } \\
\text { commerce }\end{array}$ & $\begin{array}{l}\text { University } \\
\text { of } \\
\text { Commerce }\end{array}$ & 2001 & \\
\hline
\end{tabular}

\section{Conclusions}

Currently, since the historical city has not been perceived as a system, but a pile of objects, the preservation criteria has depended on the objects themselves.

During the transformation processes of historical industrial buildings on the shoreline of Halic: 
- The historical buildings were considered as a pile of objects rather then being considered as a system

- The relationships between the buildings were ignored

- The transformation projects were not integrated with the city plan

- Although they brought economic rejuvenation in the area, they did not create social and cultural developments

- During the design processes of the projects, participation was not attained.

On this ground, Halic, Camialti and Taskizak Dockyards, whose transformation processes have not yet been started because of institutional and political problems will constitute the new dynamics of further transformations in the area. These projects will carry the potential of changing the direction and form of the current transformation. Considering previous experiences, it is expected that a new vision for urban transformation projects will be developed, which takes into account the integration of the transformed areas with their environments and an active participation of related actors who might be effect by the results of the transformation processes.

\section{References}

[1] For instance, see, Harvey, David. Spaces of Hope, Berkeley, Los Angeles, CA: University of California Pres, 2000.

[2] Cullingworth, B., Planning in the USA Policies, Issues and Processes, London, 1997.

[3] Ding, C., Knaap, G., Property values in inner-city neighborhoods: The effects of homeownership, housing investment, and economic development, Housing Policy Debate, 13, 4, 701-727,2003.

[4] Roberts P., Sykes H. (ed) ; Urban Regeneration a Handbook, London, Thousand Oaks, New Delhi: Sage Publications, 2000.

[5] Kocabaş, A., Kentsel Dönüşüm/yenileştirme, İstanbul, Literatür Yayıncilık, 2006.

[6] Koffka, K., Principles of Gestalt Psychology. Harcourt Brace. New York City NY. 1963.

[7] Perls, F.S., Hefferline, R.F., Goodman,P., Gestalt Terapisi, İstanbul, Söz yayin, 1996.

[8] Schultz, D.P., Schultz,S.E.,Modern Psikoloji Tarihi [A History of Modern Psychology], Kaknüs Yayınları, Istanbul, 2001.

[9] Norberg-Schulz, C., Genius Loci, Towards a Phenomenology of Architecture, Rizzoli, New York, 1979.

[10] Trancik, R., Finding Lost Space, Theories of Urban Space, Van Nostrand Reinhold, New York, 1986.

[11] Korkmaz, T., "On the Regeneration of the Golden Horn," Hashim Sarkis, H., Mark Dwyer, Pars Kibarer, (eds.), Two Squares: Martyrs Square, Beirut and Sirkeci Square, Istanbul, Cambridge, MA and London, UK: Harvard University, Graduate School of Design. Pp. 96-113 
[12] Amicis, E., İstanbul, Kültür ve Turizm Bakanlığı Yayınları:382, Ankara, 1986.

[13] Mantran, R., 17. Yüzyılın İkinci Yarısında İstanbul, 2, Türk Tarih Kurumu, Ankara, 1990.

[14] Kuban, D., "The Growth of a City: From Byzantium to Istanbul", Biannual Istanbul, Selections, Spring 96, pp.10-42, 1996.

[15] Bilgin, I., Modernizmin Şehirdeki İzleri, Arkitera Forum, October 2002 $<\mathrm{http} / / / \mathrm{www}$.arkitera.com/v1/diyalog/ihsanbilgin/modernizm1.htm>

[16] Çelik, Z., 19.Yüzyılda Osmanlı Başkenti: Değişen İstanbul, Tarih Vakfı Yayınları, İstanbul, 1998.

[17] Tekeli, İ., The Development of the Istanbul Metropolitan Area, Urban Administration and Planning, IULA-EMME, Yıldız Technical University, İstanbul.

[18] Tekeli, İ., “19. Yüzyılda İstanbul Metropol Alanının Dönüşümü” [The Transformation of Istanbul Metropolitan Area in the 19th Century], Paul Dumont, François Georgeon (ed.) Modernleşme Sürecinde Osmanlı Kentleri [Villes Ottomanes a la fin de L'empire], Trans. By Ali Berktay, Tarih Vakfi Yurt Yayınları, p:28, 1999.

[19] Roberts, Peter and Hugh Sykes, eds. Urban Regeneration: A Handbook. London, UK and Thousand Oaks, CA: SAGE, 2000.

[20] Hamnett, C., The Blind Men and the Elephant: The Explanation of Gentrification, Transactions of the Institute of British Geographers, New Series, Vol. 16, No. 2. pp. 173-189,1991. 